Journal of Sustainable Development of Transport and Logistics

journal home page: https://jsdtl.sciview.net

Drozhzhyn, O., \& Revenko, O. (2018). Container shipping in period of Freight Conference breakup. Journal of Sustainable Development of Transport and Logistics, 3(1), 53-59. doi:10.14254/jsdtl.2018.3-1.5.

\title{
Container shipping in period of Freight Conference breakup
}

\section{Oleksii Drozhzhyn (D), Oksana Revenko}

Institute of Maritime Business, Odessa National Maritime University,

Mechnikov Street, 34, Odessa, Ukraine, 65029

Department of Fleet Operations and Marine Transportation Technology

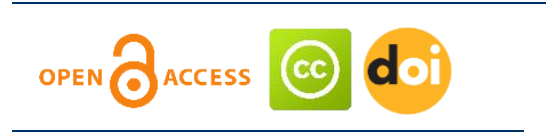

\section{Article history:}

Received: December 23,

2017

1st Revision: February 7,

2018

Accepted: March 10, 2018

\section{DOI:}

10.14254/jsdtl.2018.3-1.5

\begin{abstract}
The most important development in the liner shipping industry last 10 years was the repeal of the block exemption that Liner freight conferences had received in the European Union (EU) with regard to price and capacity settings. From of 18 October 2008, former members of the Far East Freight Conference have had to establish their specific rates and freight additions, resulting in different rates and amounts applied across the board. This paper examines the general conditions of competition in a market economy, as well as special conditions for competition in the market for liner transportation, regarding descriptive analysis summarized the available information on the subject. The study is based on EU documents, official EU reviews, and paper of international researchers on the issue of current state and prospects of liner shipping market development. In particular, the history of the emergence and formation of linear conferences and overviews the European Union decision and impact of the repealing it's block exemption from European competition law for Liner shipping conferences. As a result, the causes and implications were identified of these changes to liner container shipping industry.
\end{abstract}

Keywords: liner shipping conferences, Repeal of the Liner Shipping Conference Exemption from European Union Competition Law, trading competition.

\section{Introduction}

The concept of perfect competition looks like this:

1. significant depth of the market, i.e. the presence on the market of a large number of buyers and sellers, none of which can significantly affect the market, and the market is sufficiently liquid, so that it is capable of expanding business activity, and the growth in purchase and sale volumes has a slight effect on the price level;

2. services are available in any quantity, i.e. in any large or small, and are congenerous in quality, thus, do not differ in their consumer value depending on the brand; 
3. availability of free and complete information on the market;

4. the lack of cooperation and secret agreements between buyers and sellers.

Of course, there are no such ideal conditions in any real market, moreover, the conditions of real competition depend on circumstances, the entire complex of which cannot be taken into account either practically or theoretically. For example: large firms produce services that are cheaper than small ones; diversification and expansion of the range of services of carriers - shipping lines usually help them to obtain competitive advantages. Thus, the development of multimodal transport, in particular door-todoor transport, the provision of additional services-the storage of goods in a warehouse, the provision of containers for leasing, etc., transport services make it possible to save and break the balance of the market in their favor.

Let's take a closer look at the factor that has been significantly developed in the market of liner transportation - at the conclusion of agreements that are aimed at the emergence of long-term relationships. Such contracts between shipping lines are called line conferences, and between cargo owners - shippers' councils.

"Liner conferences, also called "shipping conferences" or "ocean shipping conferences", have had the most significant influence on competition in the liner shipping market compared to other organizational forms of operation. Liner conferences are "formal or informal private arrangements between carriers or between shipping lines which enable them to utilize common freight rates and to engage in other cooperative activities on a particular route or routes" (OECD, 2002b: 16).

The United Nations Convention on a Code of Conduct for Liner Conferences, 1974, 9 defines liner conferences as: "A group of two or more vessel-operating carriers which provides international liner services for the carriage of cargo on a particular route or routes within specified geographical limits and which has an agreement or arrangement, whatever its nature, within the framework of which they operate under uniform or common freight rates and any other agreed conditions with respect to the provision of liner services" (UNCTAD, 1974: 4).

Throughout the history the discussion in variety of countries and on different regional governmental and business levels according to historical and plot of the appearance and governmental allowance liner shipping conferences way of business is justified, due to the fact that liner shipping area has the tendency to overcome more expenses and irregularities comparing to producers and shippers around the world, such a s very large initial capital investment, overcapacity and there huge non-cargo costs etc. As a result, it was argued that without collective freight rate and unrestrained competition would lead to the competition, which is "destructive" and furthermore, occurs instability of prices and undesirable oligopoly (UNCTAD, 2016).

According to such reasons and other factors, which are underlined in this article, European Union (EU) announced the repeal of EC Regulation No. 4056/86 on September 25, 2006, which provides «a block exemption from EU computational law for liner shipping conferences in EU trades. (Federal Maritime Commission, 2012). It was also announced the two-year transition period till October 18, 2008, before the repeal would take effect.

\section{Research methods}

The review is the result of a descriptive analysis to determine the impact of changes in legislation on commercial activities in the liner shipping industry. The main research tools are general scientific and analytical methods. Information support includes: statistical data, legal documents and forms, commercial contracts.

\section{Evolution and transformation of liner conferences in shipping business}

In 1860, the first agreement was concluded between British shipowners servicing the Europe-Far East direction, and 15 years later the first shipping conference 1 was established, already regulating the freight rates on the direction Great Britain-India (Calcutta). Calcutta conference, created in 1875, is considered to be the first cartel in the field of liner transportation.

Further, other conferences with different characteristics and degree of consolidation began to emerge, covering other transportation regions. The prevailing part of the shipping cartels carried out transportation on international routes. The same shipowner company could be a participant in several 
international cartels operating in different directions. The number of participants in one conference could reach up to 100 or more shipping companies. Typically, large shipping companies were members of all or most of the conferences in a particular geographic area and determined their policies in their own interests at the expense of small and medium-sized ship owners.

The conferences could be open and closed. In open conferences the admission of new members was freer. They could join any shipping companies that have expressed a desire to participate in the association and are obliged to comply with the relevant tariff and other arrangements.

The most free form of the agreement was the so-called "gentlemen's", which were rarely made out in writing. All the "gentlemen's" agreements had no legal basis. In a short time, such cartels have spread widely in many countries, being a means of circumventing antimonopoly legislation (Kanuk, 1984).

The most solid form of the shipping cartel was the agreements of shipping lines agreements or shipping pools. The pools could differ, starting from agreements that control the distribution of the number of shipboard waste streams to the pools, to agreements that provide for control over the distribution of freight or freight revenue, as well as the companies' profits from transport. Based on the actual results of transportation after a certain period (pooling period), the pool members' share in the transportation region could be revised.

Later, there were also forms of monopoly associations in the form of inter-conference agreements or associated conferences-conference conferences. They usually arose between conferences serving nearby destinations or districts, in order to reduce the intensity of competition among the linear carriers that make up their line-up.

In the second half of the 20th century, there were more than 300 different in the world structure and degree of monopolization agreements covering the majority of shipping lines.

The existing market conditions forced ship owners to determine their status. In particular, the shipping company could be: a member of the conference - fully adhering to the conference tariffs and other rules; admitted by an outsider - an associate member of the conference, whose tariffs could differ from the conference tariffs, but their magnitude has always been coordinated with the conference; independent carrier-outsider - independently determining tariffs and freight policy.

Under such circumstances, when most of the linear carriers were merged into shipping cartels, their market position was more stable than the position of consignors who could not protect their interests in an organized manner. The unequal position of linear carriers and charterers often led to crises in the transportation market and caused damage to foreign trade of individual countries.

The beginning of a new phase in the relationship between charterers and liner conferences can be designated as the formation of the Council of British Shippers in 1955 (The British Shippers Council). Since then, there has been a practice of mutual consultation between consignors and line conferences. Based on the recommendations of the International Chamber of Commerce, such unions were established in many countries around the world (Pons \& Fitzgerald, 2002). The main requirement of consignors or charterers to linear carriers was the stabilization of the tariff level, which is in the interests of international trade.

The second factor is a significant increase in the carrying capacity of world tonnage by the middle of the 20th century, which led to a significant excess of supply over demand in the global freight market. In parallel, independent lines were able to increase their tonnage and penetrated many of the conference lines, which in some cases led to the collapse of conferences or to the weakening of their monopoly influence in certain geographical markets.

The shipping lines, as the struggle intensified, widened the range of funds that could keep their market share. The struggle for clientele began. To do this, often used so-called confidential discounts for customers, violating tariff arrangements within cartels (European Commission, 2008).

The third factor is the increasing criticism of the conduct of linear conferences by governments, shippers and shipping lines of developing countries.

The national ship owners of Europe and Japan in 1971 responded to this criticism by creating a Code of Practice for linear conferences - the KENSA Code. The purpose of the document was to strengthen the confidence in the effectiveness of the system of conferences. It was called upon to protect the conference from accusations of dishonesty and discrimination by observing a high level of fair practice. The UNCTAD Working Group on International Maritime Law in 1972 considered the "KENSA 
Code". However, delegations from developing countries refused to support the "KENSA Code" (APEC, 2008b).

In addition to the KENSA Code, there were also projects of African and Asian developing countries and Latin America and the UNCTAD project with the idea of international control. On the basis of these documents, a compromise was formed. On 6 April 1974, the Convention on the Code of Conduct for Linear Conferences was adopted in Geneva, which entered into force in 1983 (UNCTAD, 2016) (hereinafter referred to as the Convention). The Convention was ratified by the USSR in 1979 with a reservation. The Government of the USSR indicated that the provisions of the Convention do not apply to joint shipping lines established on the basis of intergovernmental agreements to serve the bilateral mutual trade turnover of the countries concerned (Wang, 2014).

A number of theses of the Convention deserve special attention:

- tariff rates should have been set at such a low level as is commercially feasible, and should have allowed ship owners to make a reasonable profit;

- the conferences were to notify the consignors for 150 days about their intention to raise the tariff rates, indicating its size, the date of implementation and the reasons justifying the proposed increase;

- between conferences and consignors, consultations on issues of mutual interest should be held at the request of either party no later than 30 days after the receipt of the proposal for consultations.

Thus, the Convention brought consignors-consumers to a new negotiating level with carriers, which was a very important factor in stabilizing the market for liner transportation (Lemper \& Zachcial, 2008).

The fourth law that has had a great impact on the development of linear navigation in the world and the state of conferences, in particular, was the US Shipping Act of 1998 (The Ocean Shipping Reform Act, OSRA). Despite the fact that the law of OSRA retained the right of immunity for linear conferences for linear conferences, in fact, it restricted their ability to effectively influence the activities of their members. The conferences were deprived of the right to prohibit or restrict the conclusion of individual service contracts by conference participants. At the same time, everyone was obliged to provide confidential information about the terms of service contracts to the US Federal Maritime Commission.

The fifth factor is the large mergers and acquisitions that took place, as a result of which the world container transport industry reached an unprecedented concentration. If in 1990 the twenty largest linear carriers controlled about $40 \%$ of the container capacity of the world fleet, then in 2000 the twenty largest liner carriers controlled $81 \%$ of the tonnage.

The totality of the factors and events described has triggered a change in the market. The transition to the modern state and the emergence of different legalized cartels from the conferences, to agreements on the joint use of ships and a part of their container capacity (vessel-sharing, slot-charter, space-charter agreements). Already from the middle of the 90's of the XX century, almost all large container carriers operated within the framework of a global partnership - alliances. According to US FMS statistics, in 2001 agreements on joint agreements, including strategic alliances, accounted for $58 \%$ of all existing agreements.

\section{Idea of the liner conferences}

International maritime shipping is uncontrolled by anyone. Unlimited competition becomes unlimited. As Kendall writes in his work "The Marine Business" "Victims of the predatory policy of some overly aggressive shipowners are not only other shipowners, but also consignors, as well as consumers." It would be necessary to create such an international body that would be able to regulate the level of freight rates and regulate the conditions of competition with the independence of individual carriers.

Due to the absence of such a body, a system of liner (freight) conferences was established.

The system of liner transport conferences arose as a result of unlimited competition, which was aggravated in the conditions of unlimited competition, which was aggravated by the rapid growth of the tonnage of the world fleet in the second half of the last century, in certain areas of world trade.

The first liner conference was established in 1875 in the direction of maritime trade LondonCalcutta, which was called the "United Kingdom Calcutta Conference". Participants in this conference believed that such an agreement would help stabilize freight rates, conditions for the carriage of goods 
by sea and ship schedules, and would provide more convenience to importers and exporters. It was this conference that initiated the wide development of cartelization in liner shipping.

The initial task, which was solved by the conference agreements, was limited to price competition in order to prevent competing shipping companies from sinking each other. There are cases when "freight wars" flared between competing companies (Helbling, 1992).

The conference agreements, however, do not regulate other forms of competition. These include improving the quality of service - reducing the delivery time, increasing the safety of cargo, additional freight forwarding services. The competition in advertising activity is not limited (European Commission, 2007).

The basic agreements on international maritime transport were concluded at the International Conference on the Law of the Sea, held in Brussels in October 1922. In 1924, the Brussels Convention on the unification of certain rules on bills of lading (The Hague Rules) came into force. States that have ratified this convention subsequently passed laws that included the convention in national law (CMA CGM site, 2013).

European Union decision and its impact on the maritime trading area

In the European Union (EU), in due time, in accordance with EU Directives 4056/86 (1986), $870 / 95$ (1995, as amended 2000), linear conferences and consortiums were granted the right to exemption from EU antitrust requirements. However, under the pressure of European shippers in 2004, the European Commission (EC) adopted a Regulation on which the requirements for free competition art. $81 \mathrm{EU}$ agreements entered into force for tramp and short sea shipping from 18.10.2006, and for line navigation - from 18.10.2008.

The global economic crisis in 2008 and the overproduction of container carriers led a linear navigation to the industry crisis. Against the backdrop of this situation, on September 30, 2009, the EC extended the block of exceptions for line navigation from antimonopoly legislation for 5 years until April 2015. In 2014, after various consultations, the EC passed a resolution extending the existing exceptions for consortia for another five years until April 2020 (Hetherington, 2015).At the end of this period, the EC plans to revisit the market and decide the relevance of further exceptions for the lines.

EC believes that, unlike conferences, consortia are a form of technical cooperation. The consortium can be organized in various forms, from a fully integrated cooperation, often called an alliance, to a simple exchange of space on ships from each other. The joint market share of the consortium members cannot exceed $30 \%$ of the total market volume (Pons \& Fitzgerald, 2002).

The EC's arguments on consortia (alliances) are quite contradictory. On the one hand, it is difficult to disagree with the fact that high service parameters can only be supported by joint efforts of a group of carriers (for example, two or three calls to one port within one week). On the other hand, one can not agree with the assertion that cooperation within the alliances allows participation in the transport of both large and small carriers, with an equal for all result. It is also possible to call into question the assertion that the consumers of services enjoy the benefits of alliances equally, like the carriers.

In favor of these arguments, drawing attention to the fact that on 21.11.2013 the EC launched an official antitrust investigation against 14 liner shipping companies to understand whether the concerted actions of the lines are a violation of EU antitrust rules. The EC notes that the carriers made regular public statements to increase the basic freight rate (GRI) through press releases on their websites and in the specialized industry press, which, as a rule, are the same for all carriers. EC believes that such a practice can be a signal for other carriers of the intention to raise prices and may harm the competition and consumers. It is found that the size of BAF varies even in the lines, which entered into agreements on mutual use of ships on a common service: "the difference between the level of BAF lines CMA-CGM and Maersk in the Far East in September 2011 is 12.2 \%". (Drozhzhyn \& Tikhonina, 2011).

In this regard, the issue of the permissibility of existing operating agreements and their actual impact on competition, the level of prices and consumers requires additional in-depth analysis and research. In support of this argument, the Chinese regulator has forbidden the creation by the three largest players in the linear container market (Maersk, MSC, CMA CGM) of the P3 Network alliance, and the EC's intention to revisit the market in 2020 and decide the relevance of further antimonopoly relaxations for lines.

In conclusion, in the EU countries, the United States and Asia, linear container transportations are in orbit of special attention, sometimes exceeding the limits of regulation within their jurisdiction [20]. 
The effect of the repeal of the liner conference block exemption in Europe was likely to be relatively modest (due to the fact that it has a minimal intervention impact), the market power if carrier agreements which was terminated had already been extremely limited by earlier regulatory reforms and legal interventions. In other words, any effect of the block exemption was likely to be not only small, but also masked by the deeply felt effects of the global recession. It is clear that only now the markets are recovered enough to allow an appropriate assessment of the impact of the block exemption.

\section{Conclusion}

As per European Liner Affairs Association (ELAA) the container volumes only on the Asia-Europe trade market fell by around $15 \%$ in 2008. At the beginning of 2009 tariffs on this range were about 300 USD/TEU, so a fall of around $80 \%$ compared to the end of 2007. In an effort to shore up rates after the abolishment of European liner conferences , American President Line, Hapag and MOL all announced increases of the rates to levels higher than the spot price from the 1 of April 2009. As an additional measure to absorb capacity, some shipping lines rerouted their schedules from Europe to Asia to transit the longer route. While this increased average sailing times on the rotes by seven days and bunker consumption up $30 \%$, the route eliminates Suez transit charges. As a consequence of rerouting, the revenues for the Suez fell by over $22 \%$ in April 2009 compared to the same period in 2008. During April 2009, 1482 ships transited the Canal, incurring fees 448.9 million. In addition to saving fuel and absorbing spare capacity, rerouting vessels around the Cape of Good Hope avoids the piracy hot spot off Somalia and need to purchase an additional insurance.

Due to above mention, the popularity of the joint services had increased, shipping companies offer competitive rates on the all-in basis and develop their own pricing policy independently. The separation of the incidence and reconciliation of the cooperation brings competition on the new level of transparent cooperation, what has the positive effect on the shipping market at all.

\section{Appendix A. Supplementary material}

Supplementary data associated with this article can be found, in the online version, at https://jsdtl.sciview.net

\section{Funding}

The authors received no direct funding for this research.

\section{Citation information}

Drozhzhyn, O., \& Revenko, O. (2018). Container shipping in period of Freight Conference breakup. Journal of Sustainable Development of Transport and Logistics, 3(1), 53-59. doi:10.14254/jsdtl.2018.31.5 .

\section{References}

APEC (2008). Liner shipping competition policy: Non-ratemaking agreements study (stages 2\&3). Asia-Pacific Economic Cooperation (APEC) Transport Working Group (TWG). Retrieved from: http://www.apectptwg.org.cn/new/Archives/tpt-wg32/Maritime/Final/08_tpt_Liner_Stages\%202and3.pdf.

BBC News. (2014). China rejects shipping alliance. Retrieved from http://www.bbc.com/news/business27898675.

CMA CGM. (2013). CMA CGM, Maersk Line and MSC to establish an operational alliance. Retrieved from https://www.cma-cgm.com/news/1/cma-cgm-maersk-line-and-msc-to-establish-an-operationalalliance

Drozhzhyn A. \& Tikhonina I. (2011). Nekotorye osobennosti formirovaniya toplivnoy sostavlyayushchey lineynoy frakhtovoy stavki (BAF) [Some features of the formation of bunker adjustment factor addition (BAF) to the liner rate]. Nauchnye trudy Sworld, 2, part 1, 52-53.

European Commission (2007). Proposal for a European Parliament and Council Regulation repealing Council Regulation (EEC) No 954/79 concerning the ratification by Member States of, or their accession to, the United 
Nations Convention on a Code of Conduct for Liner Conferences. Retrieved from: https://www.eumonitor.eu/9353000/1/j9vvik7m1c3gyxp/vitgbgiqdbzx

European Commission (2008). Guidelines on the application of Article 81 of the EC Treaty to maritime transport services. $\quad$ Retrieved hom: http://eur-lex.europa.eu/legalcontent/EN/TXT/PDF/?uri=CELEX:52008XC0926(01)\&from=EN

Helbling, T. J. (1992). Shipping Conferences: Their Future in the Face of Political and Technological Changes. Retrieved from http://digitalcommons.uri.edu/cgi/viewcontent.cgi?article=1298\&context=ma_etds

Hetherington, S. (2015) Shipping conferences - the end of the line? Retrieved from https://www.lexology.com/library/detail.aspx?g=26cc9714-1398-4dd8-b221-1676208c9025

Kanuk, L. (1984). The UNCTAD Code of Conduct for Liner Conferences: Trade Milestone or Millstone-Time Will Soon Tell. Northwestern Journal of International Law \& Business, 6, 357.

Lemper, B. Z., \& Zachcial, M. (2008). Trends in container shipping. Bern, Switzerland: Peter Lang GmbH.

Lloyd's List. (1999). List Maritime Asia. Retrieved from https://www.lloydslist.com/ll/topic/p3-network/Lloyd's.

MacKenzie, C. H., Power, M. E., \& McDorman, T. L. (1985). Liner Shipping Conferences: An Annotated Bibliography. Lanham, United States: Lexington Books.

Pérez-Mesa, J. C., Céspedes-Lorente, J. J., \& Andújar, J. A. S. (2010). Feasibility study for a Motorway of the Sea (MoS) between Spain and France: Application to the transportation of perishable cargo. Transport Reviews, 30(4), 451-471.

Pons, J. F., \& Fitzgerald, E. (2002). Competition in the maritime transport sector: a new era. Competition policy newsletter, (1), 10-14.

Premti, A. (2016). Liner shipping: is there a way for more competition? Retrieved from http://unctad.org/en/PublicationsLibrary/osgdp2016d1_en.pdf

Psaraftis, H. N., \& Kontovas, C. A. (2010). Balancing the economic and environmental performance of maritime transportation. Transportation Research Part D: Transport and Environment, 15(8), 458-462.

Szakonyi M. (2014) CKYHE Alliance gets US regulatory blessing. Retrieved from https://www.joc.com/maritimenews/container-lines/evergreen-line/ckhye-alliance-gets-us-regulatory-blessing_20141204.html.

Tsamboulas, D., Chiappetta, A., Moraiti, P., \& Karousos, I. (2015). Could Subsidies for Maritime Freight Transportation Achieve Social and Environmental Benefits? The Case of Ecobonus. Transportation Research Record: Journal of the Transportation Research Board, (2479), 78-85.

Wang, M. (1997). The Rise of International Trade and Global Logistics in East Asia: The Case Study Emphasizing Asian NIEs. Study of Shipping Economy, 31, Japan Society of Shipping Economics, 117-135.

Wang, M. (2014 a). The Global Logistics System in East Asia (2nd ed.). Beppu, Japan: TENDODO BOOKS.

Wang, M. (2014). Global Logistics and Shipping Alliance. Beppu, Japan: TENDODO BOOKS.

Wood, D. B. (1995). International Logistics. New York, USA: Chapman \& Hall.

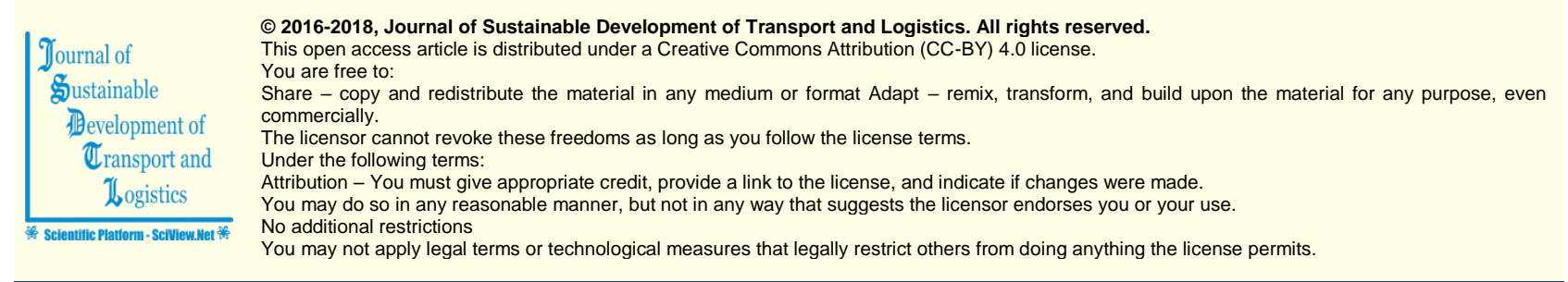

Journal of Sustainable Development of Transport and Logistics (ISSN: 2520-2979) is published by Scientific Publishing House "CSR", Poland, EU and Scientific Publishing House "SciView", Poland, EU

Publishing with JSDTL ensures:

- Immediate, universal access to your article on publication

- High visibility and discoverability via the JSDTL wobsite

- Rapid publication

- Guaranteed legacy preservation of your article

- Discounts and waivers for authors in developing regions

Submit your manuscript to a JSDTL at https://jsdtl.sciview.net/ or submit.jsdt|@sciview.net 